\title{
Накопление и распределение мышьяка в дикорастущих растениях даурской степи в условиях техногенеза
}

\section{Accumulation and distribution of arsenic in wild plants of the Dahuri steppe under conditions of technogenesis}

\author{
Бондаревич Е. А. ${ }^{1}$, Михайлова Л. А. ${ }^{1}$, Витковский Ю. А. ${ }^{1}$, Солодухина М. А. ${ }^{2}$, \\ Коцюржинская Н. Н. ${ }^{1}$, Нольфин Н. А. ${ }^{1}$ \\ Bondarevich E. A. ${ }^{1}$, Mikhailova L. A. ${ }^{1}$, Vitkovsky, Yu. A. ${ }^{1}$, Solodukhina M. A. ${ }^{2}$, \\ Kotsyurzhinskaya N. N. ${ }^{1}$, Nolfin N. A. ${ }^{1}$ \\ 'Читинская государственная медицинская академия, г. Чита, Россия. E-mail: bondarevich84@mail.ru \\ ${ }^{2}$ Институт природных ресурсов, экологии и криологии СО РАН, г. Чита, Россия \\ ${ }^{1}$ Chita State Medical Academy, Chita, Russia \\ ${ }^{2}$ Institute of Natural Resources, Ecology and Cryology SB RAS, Chita, Russia
}

Peферат. В исследовании представлены данные об уровне загрязненности почв, техноземов и растений мышьяком. Выявлено, что техногенные ландшафты села Хапчеранга имеют критический уровень загрязнения токсикантом. В селитебной зоне, расположенной вблизи (50-150 м) от промышленно складированной пустой породы, степень загрязненности почвы также имеет высокие показатели. Эти факторы крайне опасны для населения, так как растения, растущие на отвалах, и растениеводческая продукция и передают в пищевые цепи мышьяк. Выявлено, что в начале вегетации уровень загрязненности мышьяком растений в целом имеет низкие показатели, а степень поглощения данного элемента по коэффициенту накопления позволяет отнести его к группе очень слабого накопления и захвата. Совокупная оценка накопления мышьяка по абсолютному содержанию в растениях из разных зон контаминации выявила значимые отличия между техногенной и фоновой зонами $(\mathrm{H}=7,05, \mathrm{p}=0,008)$.

Ключевые слова. Забайкалье, мышьяк, техноземы, Хапчерангинский горно-обогатительный комбинат.

Summary. The study presents data on the level contamination arsenic of soil, technozem and plants. It is revealed that the technogenic landscapes of the village of Hapcheranga have a critical level of pollution with a toxicant. In the residential area, located near (50-150 m) from industrially stored waste rock, the degree of soil contamination also has high rates. These factors are extremely dangerous for the population, as farmed crop products and plants growing on dumps transfer arsenic to the food chains. It was revealed that at the beginning of the growing season, the level of arsenic contamination of plants as a whole has low indices, and the degree of absorption according to the accumulation coefficient makes it possible to assign the trace element to a group of very weak accumulation and capture. The cumulative assessment of arsenic accumulation in plants from different contamination zones revealed significant differences between the technogenic and background zones $(\mathrm{H}=7,05, \mathrm{p}=0,008)$ in the absolute content of the element.

Key words. Arsenic, Khapcheranginsky Mining and Processing Plant, Transbaikalia, technozems.

Территория Забайкалья характеризуется богатой минерально-сырьевой базой и длительной историей развития горнорудного комплекса. Результатом действия природных и техногенных факторов на поверхности земной коры являются биогеохимические провинции и районы, в которых сложился или еще формируется определенный поток вещества и энергии. Это приводит к воздействию химических элементов и их соединений на экосистемы, и часто, к сильному загрязнению окружающей среды токсичными веществами. Одной из таких локальных техногенных биогеохимических аномалий является хвостохранилища и отработанные породы Хапчерангинского горно-обогатительного комбината (ГОКа). Предприятие занималось добычей и обогащением оловянных руд, а также выделением цинкового концентрата (Быбин, 2002). В результате деятельности ГОКа сформировались значительные объе- 
мы пустой породы, складированные в хвостохранилище и представляющие опасность, в связи с интенсивным выделением токсичных неорганических соединений. Наибольшую токсичность представляют соединения мышьяка, так как элемент, согласно ГОСТ 17.4.1.02-83, относится к 1 классу опасности и обладает канцерогенным действием.

Целью работы было исследование накопления мышьяка в дикорастущих растениях в условиях геохимической аномалии в зависимости от его содержания в почве и техноземах.

\section{Материалы и методы}

Для исследования был проведен сбор растений, которые делились на части и высушивались. Объектами исследования были следующие виды растений: кипрей узколистный (Chamaenerion angustifolium (L.) Scop.), большеголовник одноцветковый (Stemmacantha uniflora (L.) Dittrich), полынь Гмелина (Artemisia gmelinii Weber ex Stechm.), полынь Сиверса (Artemisia sieversiana Willd.), спирея средняя (Spiraea media Schmidt), нонея русская (Nonea rossica Steven), тимьян даурский (Thymиs dahuricus Serg.), тополь бальзамический (Populus balsamifera L.), крапива коноплёвая (Urtica cannabina L.), чистотел большой (Chelidonium majus L.), таран узколистный (Aconogonon angustifolium (Pall.) H. Hara), ирис низкий (Iris humilis Georgi), ревень волнистый (Rheum rhabarbarum L.), стеллера карликовая (Stellera chamaejasme L.), береза плосколистная (Betula platyphylla Sukaczev), остролодочник тысячелистный (Oxytropis myriophylla (Pall.) DC.), валериана очереднолистная (Valeriana alternifolia Ledeb.), лапчатка пижмолистная (Potentilla tanacetifolia Willd. ex Schltdl.), таран растопыренный (Aconogonon divaricatum (L.) Nakai ex Mori), пятилистник мелколистный (Dasiphora parvifolia (Fisch.) Juz.), подорожник большой (Plantago major L.), шлемник байкальский (Scutellaria baicalensis Georgi). Bсего исследовано 95 проб растений и 47 почвенных образцов и техноземов.

После измельчения и мокрого озоления растительных образцов определяли содержание $\mathrm{As}^{+3}$ методом инверсионной вольтамперометрии (ИВА) (анализатор «ТА-Универсал») после восстановления сульфатом гидразиния (Методические ..., 2005). Для анализа почвенных образцов использовали аналогичную пробоподготовку. Содержание мышьяка определяли двумя методами: вольтамперометрическим (ИВА) и масс-спектрометрии с индуктивно-связанной плазмой (ИСП МС). Статистическая обработка проводилась в программе TA-Lab, по полученным данным рассчитывались среднее значение и ошибка среднего, в программе PAST 3.0 - расчет медиан и оценка значимости данных по критерию Краскала-Уоллиса (Hammer Ø, et al., 2001). Сравнение полученных данных проводили с нормативом для почв согласно ГН 2.1.7.2041-06, по которому ПДК мышьяка в почве составляет 2 мг/кг. Однако этот показатель часто не выполняется даже для не загрязненных мышьяком районов. По этой причине предложены следующие оценочные градации накопления мышьяка в почвах: величина коэффициента концентрации (отношение содержания мышьяка в почве к его кларку, Кк) меньше 1 указывает на отсутствие загрязнения, от 1 до 2 - на слабую степень загрязнения, а более 2 -х - на сильное загрязнение (Ермаков и др., 2018) Содержание мышьяка в растениях проводили в сравнении с фоновым значением для природных ненарушенных экосистем в растениях Восточного Забайкалья - 0,11 мг/кг (Ермаков и др., 2018) и для техногенно нарушенных территорий (окрестности поселка Шерловая гора) - 0,5 мг/кг (Солодухина, 2012).

\section{Результаты и их обсуждение}

Накопление мышьяка в почвах и техноземах, площадки для отбора которых находились непосредственно возле разрушенной фабрики горно-обогатительного комбината и хвостохранилища, было максимальным и характеризовалось величинами 325,64 мг/кг (метод ИВА) и 261,67 мг/кг (метод ИСП МC) (табл.). Данная зона, расположенная в центре поселка и прилегающая непосредственно к сельскохозяйственным землям, имеет превышение по содержанию токсиканта более чем в 160 раз и представляет территорию высокой опасности для населения. На чрезвычайную опасность также указывает и рассчитанный коэффициент концентрации (в сравнении с кларком), который имеет величину более 58 единиц (табл.). Селитебная зона села и его окрестностей имеет гораздо меньшую степень загрязненности (табл. 1), что отражается в величинах как средних, так и медианных значений, согласно данным двух методов определения. Фоновые участки имели близкие к кларковым значения содержания 
мышьяка (метод ИВА), что характеризует эти площадки как относительно малозагрязненные (по величинам рассчитанных Кс) (табл.).

Таблица

Среднее содержание мышьяка в почвах и техноземах, мг/кг

\begin{tabular}{|l|c|c|c|c|}
\hline \multicolumn{1}{|c|}{ Зоны отбора проб } & $\begin{array}{c}\text { Среднее содержание } \\
(\mathrm{M} \pm \sigma), \text { мг/кг }\end{array}$ & Медиана & Лимиты & $\begin{array}{c}\text { Коэффициент } \\
\text { концентрации, Кс } \\
\left(\mathrm{C}_{\text {пробьсред }} / \text { Кларк }\right)\end{array}$ \\
\hline \multicolumn{7}{|c|}{ Метод ИВА } \\
\hline Хапчеранга, селитебная $(\mathrm{n}=23)$ \\
\hline Хапчеранга, техногенная $(\mathrm{n}=19)$
\end{tabular}

Согласно литературным данным мышьяк - водный мигрант и основной путь его поступления в растения проходит через корневую систему (Перельман, Касимов, 1999). Однако важными факторами, ограничивающими его подвижность, являются геохимические барьеры, содержание органического вещества в почве, а также содержание в среде минералов железа, алюминия, кальция и магния, образующих с арсенат-анионами прочные соединения. Возможно, ещё одним фактором по сдерживанию активного перемещения мышьяка на сопредельные территории относительно геохимической аномалии является природно-климатический фактор района исследования. Находясь в условиях резко континентального климата, с малым количеством осадков и их неравномерным распределением в течение года, данная аномалия характеризуется медленными процессами перемещения токсиканта.

В ряде работ, посвященных изучению содержания мышьяка в дикорастущих растениях Восточного Забайкалья, произрастающих в условиях воздействия горно-обогатительных комбинатов, отмечается его накопление (Солодухина, Помазкова, 2011; Солодухина, 2012; Солодухина и др., 2012). Данные, полученные в ходе исследования, не выявили интенсивного накопления в фитомассе опасных уровней загрязнения мышьяком (рис. 1). Наибольшие цифры отмечались для видов, произрастающих в районе фабрики ГОКа (T. dahuricus - 7,55 мг/кг), хотя и в селитебной зоне имелись образцы растений с относительно большим содержанием микроэлемента (листья в молодые побеги P. balsamifera - 3,09 мг/кг) (рис. 1). Эта особенность может быть объяснена временем отбора проб растений (в начале вегетации в июне), климатическими условиями (в период сбора наблюдалась воздушно-почвенная засуха) и наличием у видов барьерных механизмов защиты от избыточного поступления мышьяка (что согласуется с данными по Шерловой горе (Солодухина, 2012; Солодухина и др., 2012)). Все рассчитанные коэффициенты накопления токсиканта в растениях с. Хапчеранга и его окрестностей имели величины менее 0,1 единицы и характеризовали мышьяк как элемент очень слабого накопления и захвата из геосред.

Накопление мышьяка в растениях из разных зон по степени загрязненности имело значимые отличия между техногенной и фоновой территорией, величина которой по критерию Краскала-Уоллиса равнялась 7,05 (при $\mathrm{p}=0,008)$. Между селитебной и техногенной $(\mathrm{H}=0,589, \mathrm{p}=0,44)$ и селитебной и фоновой $(\mathrm{H}=3,341, \mathrm{p}=0,06)$ зонами достоверных отличий по содержанию мышьяка не отмечено.

Таким образом, в ходе исследования почв и техноземов в условиях биогеохимической аномалии техногенного происхождения в окрестностях рудника Хапчеранга отмечено значительное загрязнение среды этим микроэлементом. Растения, произрастающие на этой территории, имели низкую загрязненность мышьяком. 


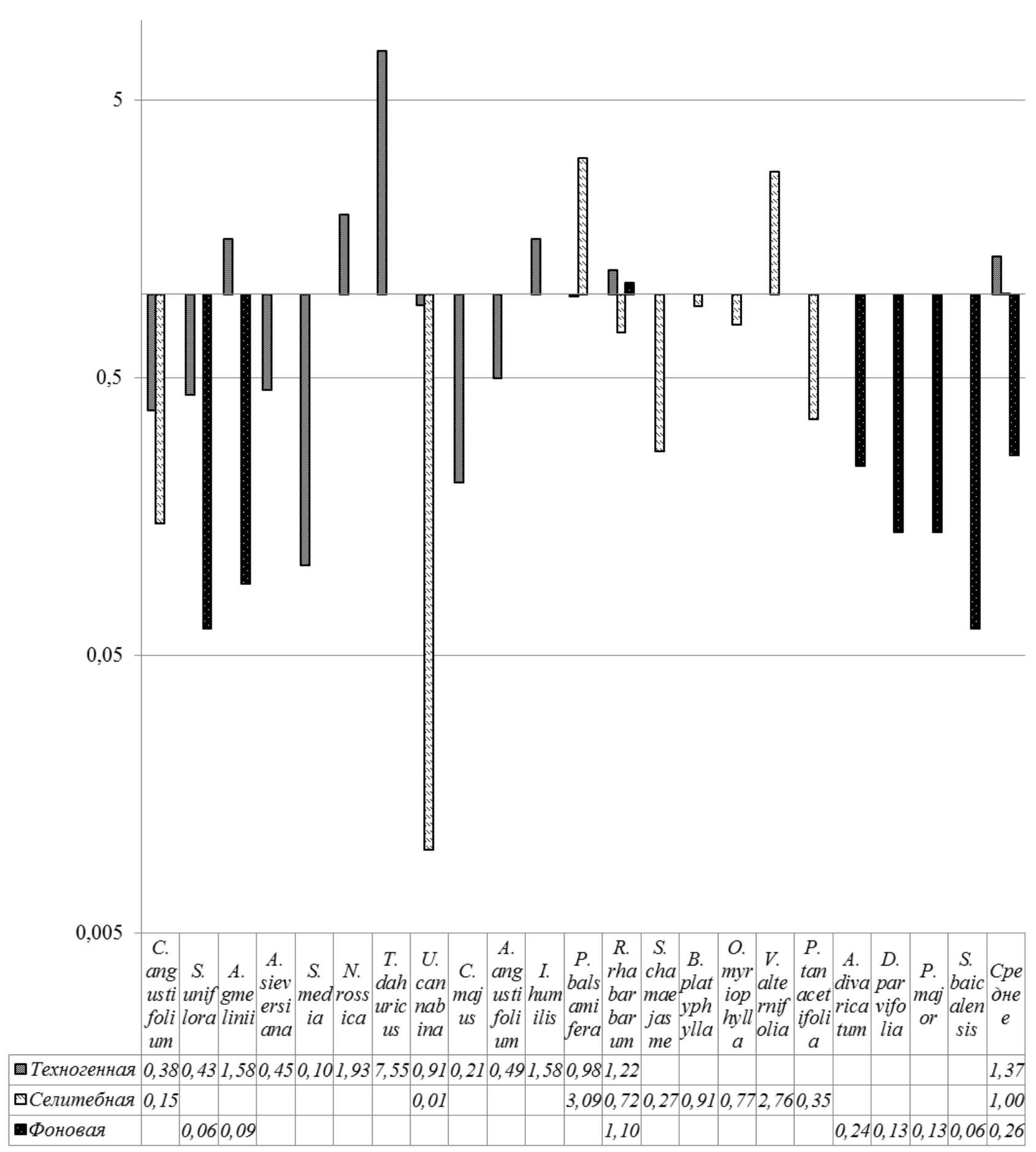

Рис. 1. Среднее содержание мышьяка в растениях, мг/кг.

\section{ЛИТЕРАТУРА}

Быбин Ф. Ф. Горно-промышленный комплекс // Энциклопедия Забайкалья. Читинская область. -Новосибирск, Наука, 2002. - Т. 1. - С. 92.

Ермаков В. В., Тютиков С. Ф., Сафонов В. А. Биогеохимическая индикация микроэлементозов. - М.: ГЕОХИ РАН, $2018-386$ c.

Касимов Н. С., Власов Д. В. Кларки химических элементов как эталоны сравнения в экогеохимии // Вестник Московского университета, Сер. 5. География, 2012. - № 4.- С. 14-24. 
Методическое указание 31-03/05. Количественный химический анализ проб почв, тепличных грунтов, илов, донных отложений, сапропелей, твердых отходов. Методика выполнения измерений массовых концентраций цинка, кадмия, свинца, меди, марганца, мышьяка, ртути методом инверсионной вольтамперометрии на анализаторах типа ТА. - Томск: НПП «Томьаналит», 2005. - 47 с.

Перельман А. И., Касимов Н. С. Геохимия ландшафта: учеб. - М.: МГУ, 1999. - С. 548-549.

Солодухина М. A. Мышьяк в компонентах ландшафтов Шерловогорского рудного района: автореф. дисс. Томск, 2012. - 20 с.

Солодухина М. А., Помазкова Н. В. Мышьяк в системе «почва-растение» в природных и антропогенных ландшафтах Забайкальского края (на примере горца узколистного (Aconogonon angustifolium Pall.) // Вестник КрасГАУ, 2011. - № 10. - C. 96-101.

Солодухина М. А., Юргенсон Г. А., Лушникова А. Ю. Мышьяк в растениях природной геохимической аномалии Забайкальского края (на примере Шерловогорского рудного района) // Ученые записки ЗабГГПУ, сер. Естественные науки, 2012. - № 1 (42). - С. 79-86.

Hammer Ø., Harpe D. A. T., Ryan P. D. PAST: Paleontological Statistics Software Package for Education and Data Analysis // Palaeontologia Electronica, 2001. - Vol. 4, No. 1. - 9 p. 